\title{
New Sulfoalkylresorcinol from Marine-derived Fungus, Zygosporium sp. KNC52
}

\author{
Kaneo Kanoh, Kyoko Adachi, Satoru Matsuda, Yoshikazu Shizuri, Ko Yasumoto ${ }^{\dagger}$, \\ Takenori Kusumi, Kayo Okumura, Teruo Kirikae
}

Received: January 15, 2008/Accepted: February 26, 2008

(C) Japan Antibiotics Research Association

\begin{abstract}
A new sulfoalkylresorcinol (1) was isolated from the marine-derived fungus, Zygosporium sp. KNC52. The structure of 1 was elucidated by spectroscopic methods including MS and NMR, and the absolute stereochemistry was determined by the modified Mosher's method. Compound 1 inhibited FtsZ polymerization in vitro and exhibited weak antimicrobial activity against multi-drugresistant bacteria.
\end{abstract}

Keywords marine-derived fungus, sulfoalkylresorcinol, FtsZ

Marine microorganisms have recently gained attention as important sources of biologically active secondary metabolites for the development of new pharmaceutical agents [1]. In particular, marine-derived fungi have shown great potential as suggested by the diversity of secondary metabolites [2]. We have been searching for novel bioactive substances, including antitumor and antibacterial agents focusing on marine-derived fungi as the screening source $[3,4]$. In the course of screening for antimicrobial substances targeting FtsZ, which is a structural homolog of eukaryotic tubulin and has an important function in bacterial cell division $[5,6]$, we found that an extract of marine-derived fungus Zygosporium sp. KNC52 inhibited
FtsZ polymerization in vitro. A new sulfoalkylresorcinol (1) was isolated from a culture extract of this fungus. Although alkylresorcinols can be found in many different living organisms such as lower and higher plants, algae, fungi, bacteria, and animals, and are important in many aspects of cellular biochemistry and physiology [7], compound $\mathbf{1}$ is the sole alkylresorcinol derivative that has a sulfoalkyl side chain. This paper describes the structural determination of $\mathbf{1}$, including its absolute stereochemistry, and its inhibitory activity against FtsZ polymerization and antimicrobial activity.

The 1-producing fungus, Zygosporium sp. KNC52, was originally isolated from a hard coral in Republic of Palau. The fungus was cultured at $25^{\circ} \mathrm{C}$ for 14 days on an agar medium containing glucose $0.5 \%$, glycerol $2.0 \%$, yeast extract $0.2 \%$, Pharmamedia ${ }^{\circledR}$ (Traders Protein) $2.0 \%, \mathrm{NaCl}$ $0.25 \%$, and agar $1.5 \%$, adjusted to $\mathrm{pH} 6.5$ before autoclaving. The cultured agar medium was extracted with

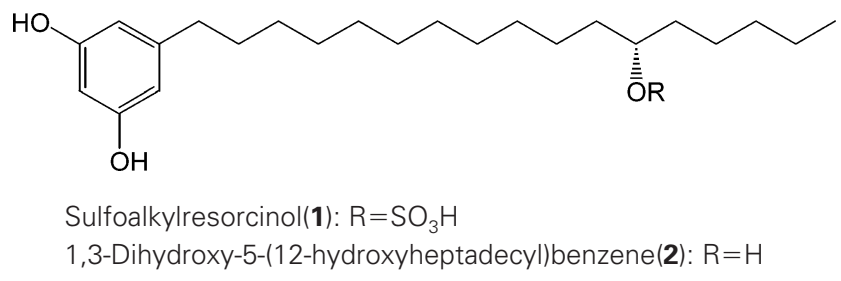

K. Kanoh (Corresponding author), K. Adachi, S. Matsuda, Y. Shizuri: Marine Biotechnology Institute Co., Ltd., 3-75-1 Heita, Kamaishi, Iwate 026-0001, Japan, E-mail: kaneo.kanoh@mbio.jp

K. Yasumoto, T. Kusumi: Graduate School of Pharmaceutical Sciences, The University of Tokushima, Shomachi, Tokushima 770-8505, Japan
K. Okumura, T. Kirikae: Department of Infectious Diseases, Research Institute, International Medical Center of Japan, 1-21-1 Toyama, Shinjuku-ku, Tokyo 162-8655, Japan

${ }^{\dagger}$ Present address: Department of Microbiology and Immunology, Shimane University Faculty of Medicine, Enya-cho 89-1, Izumo, Shimane, Japan 
$\mathrm{Me}_{2} \mathrm{CO}$, and the resulting extract was filtered and concentrated in vacuo. The concentrated aqueous residue of the $\mathrm{Me}_{2} \mathrm{CO}$ extract was partitioned with EtOAc. Inhibitory activity against FtsZ polymerization was found in the organic fraction; this fraction was concentrated to dryness and chromatographed on silica gel column, monitoring the inhibitory activity. The active fractions were combined and further purified by HPLC. Compound 1 (20 mg) was obtained as a colorless oil from 4.0 liters of the agar culture.

The molecular formula of $\mathbf{1}$ was determined to be $\mathrm{C}_{23} \mathrm{H}_{40} \mathrm{O}_{6} \mathrm{~S}$ by HRFAB-MS $\left([\mathrm{M}+\mathrm{H}]^{+} m / z\right.$ 445.2591, calcd 445.2624), which was consistent with ${ }^{1} \mathrm{H}$ - and ${ }^{13} \mathrm{C}-\mathrm{NMR}$ data. The intense IR absorption bands at 1400 and 1208 $\mathrm{cm}^{-1}$ suggested the presence of a sulfate moiety, and the negative ion ESI-MS/MS experiment, showing the unsulfated-fragment ion peak at $m / z 363\left(\left[\mathrm{M}-\mathrm{HSO}_{3}\right]^{-}\right.$) derived from the mother ion peak at $m / z 443\left([\mathrm{M}-\mathrm{H}]^{-}\right)$. The fragment ion signal of $m / z 97\left(\mathrm{HSO}_{4}^{-}\right)$in the negative ESI-MS also indicated the presence of a sulfate group.
The ${ }^{1} \mathrm{H}-\mathrm{NMR}$ spectrum indicated the presence of three meta-coupled aromatic protons at $\delta 6.01(\mathrm{~d}, J=2.3 \mathrm{~Hz}, 2 \mathrm{H})$ and $\delta 5.99(\mathrm{t}, J=2.3 \mathrm{~Hz}, 1 \mathrm{H})$, and it also showed the signals due to a long alkyl side chain at around $\delta 1.2 \sim 1.5$, a terminal methyl at $\delta 0.85(\mathrm{t}, J=6.8 \mathrm{~Hz}, 3 \mathrm{H})$, an arylic methylene at $\delta 2.35(\mathrm{t}, J=7.5 \mathrm{~Hz}, 2 \mathrm{H})$, and a sulfatebearing methine proton at $\delta 4.00$ (quintet, $J=6.0 \mathrm{~Hz}, 1 \mathrm{H}$ ). Interpretation of the ${ }^{1} \mathrm{H}-{ }^{1} \mathrm{H}$ COSY, HSQC and HMBC spectral data for $\mathbf{1}$ led to a gross structure of 1,3-dihydroxy5-(12-sulfoheptadecyl)benzene. The detailed NMR data are listed in Table 1.

The unsulfated-derivative of 1, 1,3-dihydroxy-5-(12hydroxyheptadecyl)benzene (2) was incidentally produced during the NMR measurement of $\mathbf{1}$. In the long-term NMR measurement of $1\left(10 \mathrm{mM}\right.$ in DMSO- $\left.d_{6}\right)$, the signal of a sulfate methine proton at $\delta 4.00$ decreased, and a new methine signal appeared at $\delta 3.34(\mathrm{~m})$. After 4 days, the former signal was completely replaced by the latter. This hydrolysis must have been caused by residual TFA contained in the HPLC solvent since neutralization (1 M

Table 1 NMR data of sulfoalkylresorcinol (1) and 1,3-dihydroxy-5-(12-hydroxyheptadecyl)banzene (2) (DMSO-d, $750 \mathrm{MHz}$ for ${ }^{1} \mathrm{H}$ and $125 \mathrm{MHz}$ for ${ }^{13} \mathrm{C}$ )

\begin{tabular}{|c|c|c|c|c|c|c|c|c|c|}
\hline \multicolumn{5}{|c|}{1} & \multicolumn{5}{|c|}{2} \\
\hline Position & $\delta^{13} \mathrm{C}$ & & $\delta^{1} \mathrm{H}$ & & Position & $\delta^{13} \mathrm{C}$ & & $\delta^{1} \mathrm{H}$ & \\
\hline 1 & 158.20 & C & - & & 1 & 158.10 & C & - & \\
\hline 2 & 100.01 & $\mathrm{CH}$ & 5.99 & $\mathrm{t}, 2.25$ & 2 & 99.91 & $\mathrm{CH}$ & 6.00 & $\mathrm{t}, 2.25$ \\
\hline 3 & 158.20 & C & - & & 3 & 158.10 & C & - & \\
\hline 4 & 106.31 & $\mathrm{CH}$ & 6.01 & $d, 2.25$ & 4 & 106.25 & $\mathrm{CH}$ & 6.01 & $d, 2.25$ \\
\hline 5 & 144.18 & $\mathrm{C}$ & - & & 5 & 144.15 & C & - & \\
\hline 6 & 106.31 & $\mathrm{CH}$ & 6.01 & $d, 2.25$ & 6 & 106.25 & $\mathrm{CH}$ & 6.01 & $d, 2.25$ \\
\hline $1^{\prime}$ & 35.28 & $\mathrm{CH}_{2}$ & 2.35 & $\mathrm{t}, 7.5$ & $1^{\prime}$ & 35.22 & $\mathrm{CH}_{2}$ & 2.35 & $\mathrm{t}, 7.5$ \\
\hline $2^{\prime}$ & 30.67 & $\mathrm{CH}_{2}$ & 1.47 & $\mathrm{~m}$ & $2^{\prime}$ & 30.62 & $\mathrm{CH}_{2}$ & 1.47 & $\mathrm{~m}$ \\
\hline $3^{\prime}$ & $29.22^{*}$ & $\mathrm{CH}_{2}$ & $1.18 \sim 1.28^{\$}$ & & $3^{\prime}$ & $29.15^{*}$ & $\mathrm{CH}_{2}$ & $1.20-1.34^{\$}$ & \\
\hline $4^{\prime}$ & $29.04^{*}$ & $\mathrm{CH}_{2}$ & $1.18 \sim 1.28^{\$}$ & & $4^{\prime}$ & $29.02^{*}$ & $\mathrm{CH}_{2}$ & $1.20-1.34^{\mathrm{s}}$ & \\
\hline $5^{\prime}$ & $29.04^{*}$ & $\mathrm{CH}_{2}$ & $1.18 \sim 1.28^{\mathrm{s}}$ & & $5^{\prime}$ & $28.98^{*}$ & $\mathrm{CH}_{2}$ & $1.20-1.34^{\mathrm{s}}$ & \\
\hline $6^{\prime}$ & $29.02^{*}$ & $\mathrm{CH}_{2}$ & $1.18 \sim 1.28^{\$}$ & & $6^{\prime}$ & $28.95^{*}$ & $\mathrm{CH}_{2}$ & $1.20-1.34^{\mathrm{s}}$ & \\
\hline $7^{\prime}$ & $29.02^{*}$ & $\mathrm{CH}_{2}$ & $1.18 \sim 1.28^{\$}$ & & $7^{\prime}$ & $28.95^{*}$ & $\mathrm{CH}_{2}$ & $1.20-1.34^{\mathrm{s}}$ & \\
\hline $8^{\prime}$ & $28.89 *$ & $\mathrm{CH}_{2}$ & $1.18 \sim 1.28^{\$}$ & & $8^{\prime}$ & $28.84^{*}$ & $\mathrm{CH}_{2}$ & $1.20-1.34^{\mathrm{s}}$ & \\
\hline $9^{\prime}$ & $28.66^{*}$ & $\mathrm{CH}_{2}$ & $1.18 \sim 1.28^{\mathrm{s}}$ & & $9^{\prime}$ & $28.62^{*}$ & $\mathrm{CH}_{2}$ & $1.20-1.34^{\mathrm{s}}$ & \\
\hline $10^{\prime}$ & 24.52 & $\mathrm{CH}_{2}$ & $1.25^{\#}$ & $\mathrm{~m}$ & $10^{\prime}$ & 25.17 & $\mathrm{CH}_{2}$ & $1.24^{\#}, 1.35^{\#}$ & $\mathrm{~m}$ \\
\hline $11^{\prime}$ & $33.83^{* *}$ & $\mathrm{CH}_{2}$ & $1.42,1.46$ & $\mathrm{~m}$ & $11^{\prime}$ & $37.12^{* *}$ & $\mathrm{CH}_{2}$ & $1.26^{\S}, 1.30^{\S}$ & $\mathrm{m}$ \\
\hline $12^{\prime}$ & 76.16 & $\mathrm{CH}$ & 4.00 & quint, 6.00 & $12^{\prime}$ & 69.49 & $\mathrm{CH}$ & 3.34 & $\mathrm{~m}$ \\
\hline $13^{\prime}$ & $33.78^{* *}$ & $\mathrm{CH}_{2}$ & $1.42,1.46$ & $\mathrm{~m}$ & $13^{\prime}$ & $37.10 * *$ & $\mathrm{CH}_{2}$ & $1.26^{\S}, 1.30^{\S}$ & $\mathrm{m}$ \\
\hline $14^{\prime}$ & 24.18 & $\mathrm{CH}_{2}$ & $1.25^{\#}$ & $\mathrm{~m}$ & $14^{\prime}$ & 24.86 & $\mathrm{CH}_{2}$ & $1.24^{\#}, 1.35^{\#}$ & $\mathrm{~m}$ \\
\hline $15^{\prime}$ & 31.47 & $\mathrm{CH}_{2}$ & 1.20 & $\mathrm{~m}$ & $15^{\prime}$ & 31.43 & $\mathrm{CH}_{2}$ & 1.22 & $\mathrm{~m}$ \\
\hline $16^{\prime}$ & 22.09 & $\mathrm{CH}_{2}$ & 1.26 & $\mathrm{~m}$ & $16^{\prime}$ & 22.09 & $\mathrm{CH}_{2}$ & 1.27 & $\mathrm{~m}$ \\
\hline $17^{\prime}$ & 13.93 & $\mathrm{CH}_{3}$ & 0.85 & $\mathrm{t}, 6.75$ & $17^{\prime}$ & 13.88 & $\mathrm{CH}_{3}$ & 0.85 & $\mathrm{t}, 7.5$ \\
\hline
\end{tabular}

*: interchangeable, ${ }^{*}$, : overlapping, **: interchangeable. 


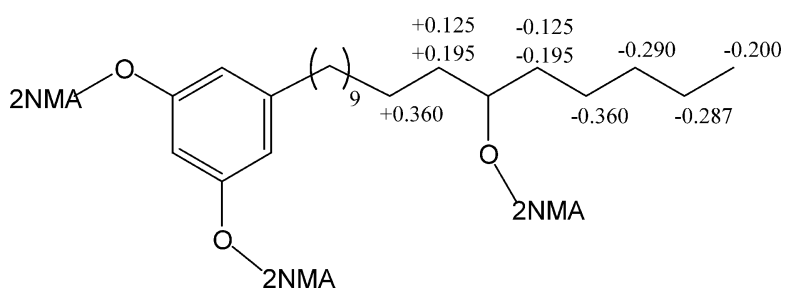

Fig. $1\left(\delta_{R}-\delta_{S}\right)$ values obtained for the 2NMA esters of 2.

$\mathrm{NaOH})$ of the NMR solvent did not bring such a change. Compound 2, $\mathrm{C}_{23} \mathrm{H}_{41} \mathrm{O}_{3}$ (HRFAB-MS: $[\mathrm{M}+\mathrm{H}]^{+} \mathrm{m} / \mathrm{z}$ 365.3056, calcd 365.3073), was recovered from the NMR solution by HPLC.

The absolute stereochemistry of $\mathbf{1}$ was established by applying the modified Mosher's method [8,9] to 2. Both the $R$ - and $S$-2NMA esters of $\mathbf{2}$ were prepared, and the proton signals around the chiral center of both derivatives were assigned by ${ }^{1} \mathrm{H}-\mathrm{NMR}, \mathrm{HSQC}$ and HMBC. The $\Delta \delta\left(\delta_{R}-\delta_{S}\right)$ values obtained are shown in Fig. 1, indicating that the absolute configuration at C-12 to be $S$.

FtsZ is a structural homolog of eukaryotic tubulin and, similar to tubulin, is a GTPase that polymerizes in a GTPregulated manner [10]. The inhibitory effects of 1 against FtsZ-GTPase and the polymerization of FtsZ were respectively measured by the methods of Margalit et al. [6] and Mukherjee et al. [11]. Compound 1 inhibited the GTPase activity of FtsZ by $50 \%$ at a concentration of $25 \mu \mathrm{g} / \mathrm{ml}$, and almost completely inhibited FtsZ polymerization at this concentration. Compound $\mathbf{1}$ also exhibited mild antimicrobial activity against Mycobcterium tuberculosis (MDR-TB), M. bovis BCG, M. avium, Pseudomonas aeruginosa (MDRP), and Staphylococcus aureus (MRSA) with respective MIC values of 166, 166, 166,50 , and $12.5 \mu \mathrm{g} / \mathrm{ml}$, but 1 did not exhibit cytotoxicity toward A549 up to $200 \mu \mathrm{g} / \mathrm{ml}$.

Acknowledgments We thank Professor R. Sakai of Kitasato University for the FABMS measurements, and Ms. T. Sasaki for her technical assistance. We also thank Mr. T. Kiyuna and M. Nishijima of TechnoSuruga Laboratory Co., LTD. for the taxonomic studies of the fungus. This work was performed as part of the project entitled "Construction of a Genetic Resource Library of Unidentified Microorganisms" supported by New Energy and Industrial Technology Development Organization (NEDO).
References

1. Blunt JW, Copp BR, Hu W-P, Munro MHG, Northcote PT, Prinsep MR. Marine natural products. Nat Prod Rep 24: 31-86 (2007)

2. Saleem M, Ali MS, Hussain S, Jabbar A, Ashraf M, Lee YS. Marine natural products of fungal origin. Nat Prod Rep 24: 1142-1152 (2007)

3. Jang J-H, Kanoh K, Adachi K, Shizuri Y. New dihydrobenzofuran derivative, awajanoran, from marinederived Acremonium sp. AWA16-1. J Antibiot 59: 428-431 (2006)

4. Jang J-H, Kanoh K, Adachi K, Shizuri Y. Awajanomycin, a cytotoxic gamma-lactone-delta-lactam metabolite from marine-derived Acremonium sp. AWA16-1. J Nat Prod 69: 1358-1360 (2006)

5. Löwe J, Amos LA. Crystal structure of the bacterial celldivision protein FtsZ. Nature 391: 203-206 (1998)

6. Margalit DN, Romberg L, Mets RB, Hebert AM, Mitchison TJ, Kirschner MW, RayChaudhuri D. Targeting cell division: small-molecule inhibitors of FtsZ GTPase perturb cytokinetic ring assembly and induce bacterial lethality. Proc Natl Acad Sci USA 101: 11821-11826 (2004)

7. Kozubek A, Tyman JHP. Resorcinolic lipids, the natural non-isoprenoid phenolic amphiphiles and their biological activity. Chem Rev 99: 1-25 (1999)

8. Ohtani I, Kusumi T, Kashman Y, Kakisawa H. High-field FT NMR application of Mosher's method. The absolute configurations of marine terpenoids. J Am Chem Soc 113: 4092-4096 (1991)

9. Kusumi T, Takahashi H, Ping X, Fukushima Y, Asakawa Y, Hashimoto T, Kan Y. New chiral anisotropic reagents, NMR tools to elucidate the absolute configurations of long-chain organic compounds. Tetrahedron Lett 35: 4397-4400 (1994).

10. Mukherjee A, Dai K, Lutkenhaus J. Escherichia coli cell division protein FtsZ is a guanine nucleotide binding protein. Proc Natl Acad Sci USA 90: 1053-1057 (1993)

11. Mukherjee A, Lutkenhaus J. Analysis of FtsZ assembly by light scattering and determination of the role of divalent metal cations. J Bacteriol 181: 823-832 (1999) 